Why Sprinklers Should Not Be Required in Open Parking Structures

A white paper prepared by the PCI Fire Committee

Cheryl Rishcoff, PE, chair

Ali Shrih, vice chair

Matthew Huslig, PE, past chair

Donavon Burns

Mark Cerminara, SE, PE

Mary Ann Griggas-Smith, PE

Paul Kourajian, PE

Gary Lentz, PE

Frank D. Maselli, LPCI

M. Z. Naser

Spencer E. Quiel, PE, PhD

Dusty E. Andrews, PE, TAC Liaison

Stephen V. Skalko, PE, Consultant

Published by the Precast/Prestressed Concrete Institute, July 2021

https://doi.org/10.15554/wp-21-01 


\section{Why Sprinklers Should Not Be Required in Open Parking Structures}

In the 2021 editions of the International Building Code (IBC) and International Fire Code (IFC), provisions were added by code change F110-18 to require automatic sprinkler protection in all open parking structures that exceed $48,000 \mathrm{ft}^{2}$ in fire area. Unfortunately, the technical documentation that was submitted to support such a drastic change to the building and fire codes did not meet the expected robustness to justify these new requirements.

This white paper provides:

- Historical background information on the fire experience in open parking structures.

- A summary of the documentation used to require sprinkler protection for open parking structures in the 2021 IFC.

- A review of the potential fire hazards in open parking structures.

- An explanation of why this added expense for the construction of open parking structures is not justified.

\section{FIRE EXPERIENCE}

Several sources have been examined to determine what the fire experience in open parking structures has been. These sources include data from the U.S. Fire Administration, market research from providers of parking structures, and the National Fire Protection Association (NFPA):

- The U.S. Fire Administration statistics show over 1.7 million fires annually (U.S. Fire Administration 2007) for the period from 1999 to 2002. Compared to this average annual number of total fires, the number of annual parking structure fires (1760 incidents) described in an NFPA study (Ahrens 2006) for the same period represents less than $0.1 \%$ of the fire incidents.

- A Parking Market Research Company study (Denda 1992) reached a similar conclusion of low risk for parking structure fires. That study looked at over 4400 fire incidences from 1986 to 1988 for general vehicle parking including structures and surface lots, with only $25 \%$ of these incidences in parking structures. During that same three-year period, approximately 7 million total fire incidents were reported. The parking structure fires for that three-year period represent about $0.016 \%$ of the total fires.

- Fire incident data collected and analyzed by NFPA in its online database for the period from 2014 to 2018 show a total of 2,453 vehicle fires in vehicle storage structures or fire stations. These data excluded single family dwellings. The total number of fire incidents reported for that period for all occupancy types is 493,797 fires. Thus, these vehicle fires represent less than $0.5 \%$ of the total fire incidents. The property loss from these 2,453 vehicle fires totaled $\$ 41,739,297$. This represents about $\$ 17,000$ per incident (NFPA n.d.).

- In a recent study of fire incidents in parking structures funded by the NFPA Fire Protection Research Foundation (Boehmer, Klassen, and Olenick 2020), one of the conclusions was, "Though fires in vehicles are 
not uncommon, large fires in parking structures are fairly rare.” The study goes on to identify that fires in parking structures can lead to significant economic losses and refers to two recent fire events (Echo Arena, Liverpool, U.K., and Stavanger Airport, Norway). There are, however, notable mitigating circumstances in both the Echo Arena (also known as Kings Dock) and Stavanger Airport fire incidents that are not necessarily relevant to parking structures in the United States. These included fire resistances for the structural elements well below what is provided in parking structures in the United States and in the case of the Echo Arena fire, a lack of control of surface fluids, which spread fire to stories below the fire incident location.

- That Fire Protection Research Foundation study also stated that "most of the large, notable parking structure fires in recent years have led to large material losses but have not involved any human fatalities and few injuries." Efforts to improve fire safety requirements in the IBC in the last decade have been focused on life safety. The record shows that life safety in open parking structures, both in terms of injuries and fatalities, is not an issue.

\section{ASSESSMENT OF FIRE HAZARDS IN OPEN PARKING STRUCTURES}

Most proponents of sprinkler systems in open parking structures cite three primary reasons to require active fire suppression:

1. Modern vehicles have much larger quantities of plastics and other combustible materials in their makeup than older vehicles. This may increase the fuel load within parking structures.

2. The trend to reduce weight in vehicles and improve gas mileage results in the move to plastic gas tanks instead of metal. This may increase the possibility that fire from a fuel spill can spread underneath adjacent vehicles, increasing the size of the fire event.

3. To reduce the use of fossil-fuel-burning devices, such as the internal combustion engine, there are more electricpowered vehicles using batteries such as lithium-ion batteries as the power source. Runaway thermal reactions within the battery casing provide a potential ignition source for a fire and increase potential ignition sources for a fire to occur within a vehicle.

These issues deserve consideration, but at present there is little real data or technical documentation to show that these factors have increased fire hazards in open parking structures significantly. The appendix lists research papers and other information pertinent to these factors examined for this paper. The main points reached from the review of these documents are:

- Though combustible content of vehicles has been increasing, the trends in vehicle fires and their impact on open parking structures are not being adversely or significantly affected. This same conclusion can be made about the use of plastic gas tanks. The fire data show that the incident rate of vehicle fires in open parking structures has remained relatively stable, though the use of plastic gas tanks has increased. Even if a structure has a sprinkler system, the vehicle itself can reduce the activation time and effectiveness of the sprinkler protection because of the shielding effect of the vehicle over the plastic gas tank. 
- There is no doubt that electric vehicles are on the rise. The most common electric vehicles use lithium-ion batteries as their source of power. The risk of fire from these batteries occurs when there is a thermal runaway of the battery cells. Though there have been isolated incidences of thermal runaway in lithium-ion batteries with no apparent cause, most instances of thermal runaway happen in vehicles due to damage sustained when the vehicle is involved in an accident. The recent comprehensive study by the NFPA Fire Protection Research Foundation (Boehmer, Klassen, and Olenick 2020) points out that "lithium-ion batteries are more difficult to extinguish than gasoline or diesel fires, requiring large amounts of water to fully contain and mitigate the hazard." Even considering increased electric vehicle use, this research raises questions about whether adding sprinklers is an effective measure for extinguishing fires caused by lithium-ion batteries because the sprinkler protection will not deliver large quantities of water to the seat of the battery fire. Also, the move to electric vehicles reduces the risk of fire spread from liquid fuels in gas tanks.

- Average property loss for fire incidents involving vehicles in storage occupancies is just over $\$ 17,000$. Compared with financial losses in other occupancies, this loss is insignificant. Some estimates put the costs to install and maintain sprinkler protection in open parking structures at approximately $\$ 3$ per $\mathrm{ft}^{2}$ for dry-pipe systems. Assuming a small 50,000- $\mathrm{ft}^{2}$ open parking structure with five tiers (total area of 200,000 $\mathrm{ft}^{2}$, not including the open top tier, which is unsprinklered), the cost of sprinkler protection would be about $\$ 600,000$. This cost cannot be justified when compared with the property loss record.

\section{IFC SPRINKLER REQUIREMENTS IN OPEN PARKING STRUCTURES}

At the time of the 2018 IFC code change cycle, there had recently been one large open-parking-structure fire that occurred in the U.K. The proposal to require sprinkler protection in open parking structures was predicated on that one incident, as reflected in the reasoning statement for Code Change F110-18. Unfortunately, all the details of that incident were not known at the time of the International Code Action Hearing $(\mathrm{CAH})$ that was held in Columbus, Ohio. Upon review of the final report by the Merseyside Fire and Rescue Service (MFRS), the parking structure in question, referred to as a "car park" in the U.K., had design features that likely contributed to fire spread between floors, resulting in a far larger number of vehicles becoming involved than normal for vehicle fire incidents (Merseyside Fire \& Rescue Service 2018). Because of these features, it is questionable whether sprinkler protection would have prevented or significantly reduced the extent of the damage.

Two of the most notable design features that likely contributed to the spread of fire in the U.K. car park incident are:

- The car park had a light-gauge aluminum drainage tray attached to the underside of each precast concrete floor panel and in line with the joint of the precast concrete floor system. The trays led to plastic vertical piping that transferred liquids to the building stormwater drainage system. The design called for a $1 / 2$-in. gap between floor panels to allow fluids to drain into the aluminum tray below. This gap in the floor joints, however, allowed burning fuel spills from vehicle gas tanks to flow directly into these aluminum trays, which then failed due to 
their low melting point. The result was fire spread to floors below, which also spread fire to vehicles on other floors.

In the United States, floor joints are typically not left open. To ensure durability they are commonly sealed by a combination backer rod and sealant or covered by the placement of a concrete topping with tooled and sealed joints. ${ }^{1}$ This not only minimizes spread of fire to floors below caused by leaking fuels, but also inhibits the spread of flames from the incident floor to vehicles on floors above.

- The building code requirements in the U.K. only required a 15 -minute structural fire resistance for the precast concrete floors for the Echo Arena car park. The fire exposure from the initial vehicle (and subsequent vehicles) damaged the underside of the floor panels above sufficiently to permit the fire to extend upward to vehicles on the next parking level.

In the United States, the typical precast concrete floor systems in open parking structures meet at least a minimum 1-hour structural fire resistance, which significantly increases the ability to prevent fire spread between floors and reduces the risk of structural failure from exposure to a vehicle fire.

\section{CONCLUSION}

From a review of the information provided, several points suggest sprinkler protection in open parking structures is unwarranted:

- The risk of vehicle fires being a major issue in unsprinklered open parking structures in the United States continues to be significantly low. Even with potential changes in materials used to construct vehicles and the possibility of nonmetal gas tanks, the fire history and property loss in recent years do not reflect any notable increase in the hazard.

- The hazard presented by lithium-ion batteries does not have a track record of numerous incidences for vehicles under normal operating conditions, whether at rest (parked) or in motion. Major incidences have occurred when the battery was subjected to adverse conditions, such as a traffic accident. The low risk of thermal runaway in lithium-ion batteries does not justify imposing the extra costs of sprinklers in open parking structures and the long-term expense to owners for maintenance of such systems in an open-weather environment.

- The Echo Arena car park fire incident in the U.K., with the large number of vehicles becoming involved due to compounding circumstances and design features contributing to fire spread, was an unusual event and is not a sufficient basis to support F110-18. The design practices and features of open parking structures in the United States, which minimize fire spread between floors and reasonably withstand the structural impact from fire effects, have an excellent record when it comes to fire incidents.

\footnotetext{
${ }^{1}$ Section 3.4.5.1 Construction Joints and Control Joints and ACI 362R, MNL 129-15, page 3-14, Precast/Prestressed Concrete Institute.
} 
Based on open parking structures having a low risk from vehicle fires in the United States and the fire safety design features for open parking structures in the IBC, the mandate for sprinkler protection in the IFC is unwarranted.

\section{APPENDIX}

Ahrens, M. 2013. Reported Structure Fires by Extent of Fire Spread, Occupancy and Loss Rates 2007-2013. Quincy, MA: National Fire Protection Association, Fire Analysis and Research Division.

Blikeng, L. S., and S. H. Agerup. "Fire in Electric Cars." In Third International Conference on Fires in Vehicles, October 1-2, 2014, Berlin, Germany. http://ri.diva-portal.org/smash/get/diva2:962841/FULLTEXT02.pdf.

International Code Council (ICC). 2021. 2021 International Building Code. Washington, DC: ICC.

ICC. 2021. 2021 International Fire Code. Washington, DC: ICC.

Long Jr., R. Thomas, and Andrew Blum. 2016. "Lithium-Ion Batteries Hazard and Use Assessment - Phase III." Final report, NFPA Fire Protection Research Foundation, Quincy, MA.

Long Jr., R. Thomas, Andrew F. Blum, Thomas J. Bress, and Benjamin R. T. Cotts. 2013. "Best Practices for Emergency Response to Incidents Involving Electric Vehicle Battery Hazards: A Report on Full-Scale Testing Results.” Final report, NFPA Fire Protection Research Foundation, Quincy, MA.

Mikolajczak, C., M. Kahn, K. White, and R. T. Long. 2011. "Lithium-Ion Batteries Hazard and Use Assessment Phase I." Final report, NFPA Fire Protection Research Foundation, Quincy, MA.

NFPA Fire Research Foundation, Lithium-Ion Battery Hazard and Use Assessment - Phase I, July 2011.

NFPA Fire Research Foundation, Lithium-Ion Battery Hazard and Use Assessment - Phase II, November 2016.

Spearpoint, M. J., M. Z. M. Tohir, A. K. Abu, and P. Xie. 2015. "Fire Load Energy Densities for Risk-Based Design of Car Parking Buildings." Case Studies in Fire Safety, vol. 3: 44-50.

Storesund, K., C. Sesseng, R. F. Mikalsen, O. A. Holmvaag, and A. Steen-Habsen. 2020. Evaluation of fire in Stavanger airport car park 7 January 2020 [RISE-report 2020:91]. RISE Fire Research.

\section{REFERENCES}

M. Ahrens, M. 2006. Structure and Vehicle Fires in General Vehicle Parking Garages. Quincy, MA: National Fire Protection Association.

Boehmer, H., M. Klassen, and S. Olenick. 2020. Modern Vehicle Hazards in Parking Structures and Vehicle Carriers. Report no. FPRF-2020-07. Quincy, MA: Fire Protection Research Foundation.

Denda, D. F. 1992. Parking Garage Fires (A Statistical Analysis of Parking Garage Fires in the United States: 1986-1988). McLean, VA: Parking Market Research Company.

PCI WP-21-01

July 2021
6

Why Sprinklers Should Not Be Required
in Open Parking Structures


Merseyside Fire \& Rescue Service (MF\&RS). 2018. Kings Dock Car Park Fire Protection Report. Merseyside, U.K.: MF\&RS.

National Fire Protection Association. n.d. Number of Fires Reported to Local Fire Departments in the United States by Property Use: 2014-2018 Annual Averages. https://www.nfpa.org/News-and-Research/Data-research-andtools/US-Fire-Problem/Fires-by-Occupancy-or-Property-Type/.

U.S. Fire Administration/National Fire Data Center. 2007. Fire in the United States 1995-2004. 14 $4^{\text {th }}$ edition. FA311. Emmitsburg, MD: Federal Emergency Management Agency. 